\title{
Cervical Esophagus Squamous Cell
} Carcinoma

National Cancer Institute

\section{Source}

National Cancer Institute. Cervical Esophagus Squamous Cell Carcinoma. NCI Thesaurus.

Code C150032.

A squamous cell carcinoma that arises from the cervical esophagus. 